\title{
Impact of atypical ammonium concentrations on phytoplankton abundance and composition in fresh versus estuarine waters
}

\author{
Mary Lou Esparza ${ }^{1, *}$, Ann E. Farrell ${ }^{1}$, Douglas J. Craig ${ }^{1}$, Curt Swanson ${ }^{1}$, \\ Bhupinder S. Dhaliwal ${ }^{1}$, Gry Mine Berg ${ }^{2}$ \\ ${ }^{1}$ Central Contra Costa Sanitation District, 5019 Imhoff Place, Contra Costa, CA 94553, USA \\ ${ }^{2}$ Applied Marine Sciences, 911 Center St, Santa Cruz, CA 95060, USA
}

\begin{abstract}
The impact of atypically high ammonium $\left(\mathrm{NH}_{4}^{+}\right)$concentrations delivered via treated wastewater effluent on phytoplankton community composition was investigated in a tidal slough connected with Suisun Bay in the northern part of San Francisco Bay. Input of effluent to a downstream location resulted in $\mathrm{NH}_{4}{ }^{+}$concentrations of (mean $\pm \mathrm{SD}$ ) $1021 \pm 380 \mu \mathrm{mol} \mathrm{l}{ }^{-1}$, compared with $2.9 \pm 1 \mu \mathrm{mol} \mathrm{l}^{-1}$ at a site further upstream, and $4.8 \pm 1 \mu \mathrm{mol} \mathrm{l}^{-1}$ in Suisun Bay. Comparison of the diatom community at the downstream site in Pacheco Slough with that in Suisun Bay revealed a substantial overlap in species, including Cyclotella scaldensis, which dominated diatom species

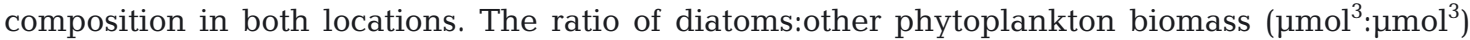
suggested that diatoms contributed a greater proportion of total phytoplankton community biomass at the downstream location $(48.6 \pm 87)$ versus in Suisun Bay $(9.5 \pm 1)$ or upstream $(9.5 \pm 8)$, and that diatoms can readily grow in the presence of $\mathrm{NH}_{4}{ }^{+}$concentrations varying from 2 to $1350 \mu \mathrm{mol} \mathrm{l}^{-1}$. In the present investigation, species composition of the seeding population was found to be a more important predictor of final phytoplankton community composition than nutrient concentrations or ratios.
\end{abstract}

KEY WORDS: Phytoplankton $\cdot$ Ammonium $\cdot \mathrm{N}: \mathrm{P}$ ratio $\cdot \mathrm{NH}_{4}{ }^{+}: \mathrm{NO}_{3}{ }^{-}$ratio $\cdot$ Diatoms $\cdot$ Chlorophytes $\cdot$ San Francisco Estuary · Suisun Bay

\section{INTRODUCTION}

Compared with other estuaries in the United States, San Francisco Bay (SFB) on the Pacific Coast distinguishes itself by having exceptionally low phytoplankton productivity and biomass (Nixon 1988, Cloern 1999). The low productivity is generally attributed to light limitation (Cole \& Cloern 1984, 1987, Alpine \& Cloern 1988, Jassby et al. 2002), resulting from relatively high levels of sediments brought via the Sacramento River into the bay (Goodwin \& Denton 1991, Ruhl \& Schoellhamer 2004, Schoellhamer et al. 2012). Phytoplankton production and community structure are also controlled by high rates of benthic filter

\footnotetext{
${ }^{*}$ Corresponding author: mesparza@centralsan.org
}

feeding as well as high flushing rates and short water residence times (Carlton et al. 1990, Alpine \& Cloern 1992, Lehman 1996, 2000, Jassby 2008). Both pose a greater threat to phytoplankton populations in the northern region (Suisun Bay) compared with the southern region (South Bay) of SFB due to a greater abundance of invasive clams and a closer proximity to the Sacramento River (Thompson et al. 2008, Cloern \& Jassby 2012).

In addition to the aforementioned factors, it has recently been proposed that the concentration of ammonium $\left(\mathrm{NH}_{4}{ }^{+}\right)$in the wastewater effluent that flows into Suisun Bay impairs phytoplankton growth (Dugdale et al. 2007, Parker et al. 2012). Moreover,

() The authors 2014. Open Access under Creative Commons by Attribution Licence. Use, distribution and reproduction are unrestricted. Authors and original publication must be credited. 
analyses of changes in nutrient concentrations and phytoplankton abundance using the cumulative sums of variability (CUSUM) statistic suggests that diatom abundance correlates positively with low dissolved $\mathrm{N}: \mathrm{P}$ ratios and with $\mathrm{NO}_{3}{ }^{-}$being the dominant $\mathrm{N}$ source in the water column (Glibert 2010). Therefore, it has been hypothesized that the moderate increases in concentrations of $\mathrm{NH}_{4}{ }^{+}$which have occurred over the past 2 decades in Suisun Bay may have affected diatoms disproportionately, potentially resulting in diatoms becoming outcompeted by cyanobacteria and flagellates (Glibert et al. 2011, but see also Cloern et al. 2012).

Decreasing diatom concentrations, whether due to clam filtration or changes in nutrients (concentrations, ratios, or forms), has become a serious issue in Suisun Bay as it is thought to be the root cause of a decrease in micro- and macrozooplankton abundance, leading to a general decline in the Suisun Bay-Delta ecosystem as a food resource for higher trophic levels (Kimmerer et al. 1994, Kimmerer 2002, Feyrer et al. 2003, Winder \& Jassby 2011). For example, the decrease in zooplankton may be adversely affecting abundances of several species of pelagic fish that have been at historical lows since 2001 (Sommer et al. 2007, Glibert 2010). This acute decline in fish abundances has prompted considerable efforts on the part of resource management agencies to identify the causes in the hope of fostering recovery (Nobriga et al. 2005, Sommer et al. 2007). Identifying the key factors contributing to the fish decline has proven difficult, as many environmental changes have occurred leading up to the year 2001 and continuing into the present (Cloern \& Jassby 2012). While regulating clam abundance or filtration rates is not easily accomplished, regulating the load of $\mathrm{NH}_{4}{ }^{+}$ discharged by local wastewater treatment plants into Suisun Bay is possible. Therefore, considerable efforts on the part of water quality managers has been expended on understanding how elevated concentrations of $\mathrm{NH}_{4}{ }^{+}$may contribute to the decline of phytoplankton in general, and diatoms in particular (Jassby 2008).

The present study investigates the impact of atypically high $\mathrm{NH}_{4}{ }^{+}$concentrations delivered via treated wastewater effluent on phytoplankton abundance and community composition in a tidal creek connected to Suisun Bay. This investigation arose fortuitously from the need to repair a discharge pipe that would ordinarily discharge effluent into the deepest part of Suisun Bay. Effluent was discharged into Pacheco Slough, a tidal slough connected to Suisun Bay, allowing close monitoring of the effect of high levels of $\mathrm{NH}_{4}{ }^{+}$in the effluent on phytoplankton abundance and community composition in a restricted volume of water. Moreover, the shallow depth and lower turbidity of the tidal slough compared with Suisun Bay avoided problems of light limitation on phytoplankton growth. This enabled us to focus solely on the effects of the effluent and to investigate whether (1) the phytoplankton community was of a different composition relative to Suisun Bay, potentially reflecting the increase in abundance of phytoplankton (e.g. flagellates, cyanobacteria) able to tolerate atypical $\mathrm{NH}_{4}{ }^{+}$concentrations, high $\mathrm{N}: \mathrm{P}$ and $\mathrm{NH}_{4}{ }^{+}: \mathrm{NO}_{3}{ }^{-}$ratios, and (2) whether the proportion of diatoms was less in Pacheco Slough, indicating that diatoms at this location were more susceptible to inhibition of growth by $\mathrm{NH}_{4}{ }^{+}$than other taxa, and if so, whether (3) the diatoms present were different than the species typically present in Suisun Bay. To answer these questions, we enumerated phytoplankton in the slough at regular intervals while the effluent was being discharged into it and compared the composition with that in Suisun Bay, as well as with a point upstream in the slough not impacted by effluent. Environmental parameters such as salinity, dissolved oxygen, $\mathrm{pH}$, temperature, turbidity, and nutrient concentrations were also monitored.

\section{MATERIALS AND METHODS}

Treated wastewater effluent from the Central Contra Costa Sanitary District (CCCSD), a conventional secondary wastewater treatment plant located in Martinez, CA on the southern shore of Suisun Bay, is usually discharged through a deep-water outfall directly into Suisun Bay. Every 8 to 10 yr the CCCSD drains, inspects and repairs its outfall. During this time, the CCCSD discharges its treated effluent into a holding basin (hereafter the basin) that flows over into Pacheco Slough, which drains into Suisun Bay (Fig. 1).

Pacheco Slough is $5.5 \mathrm{~km}$ long and ranges in width from less than $15 \mathrm{~m}$ upstream to greater than $76 \mathrm{~m}$ near the entrance to Suisun Bay. Water depth in the Slough is regulated by tidal action and ranges from less than $0.6 \mathrm{~m}$ upstream to approximately $1.8 \mathrm{~m}$ near the entrance to Suisun Bay. Pacheco Slough receives surface water runoff from the Walnut Creek and Grayson Creek watersheds of Central Contra Costa County. Grayson Creek is about $12 \mathrm{~km}$ long and originates in the Briones Regional Park, and Walnut Creek is about $56 \mathrm{~km}$ long and originates in the San Ramon Valley. The discharge from the Walnut Creek 


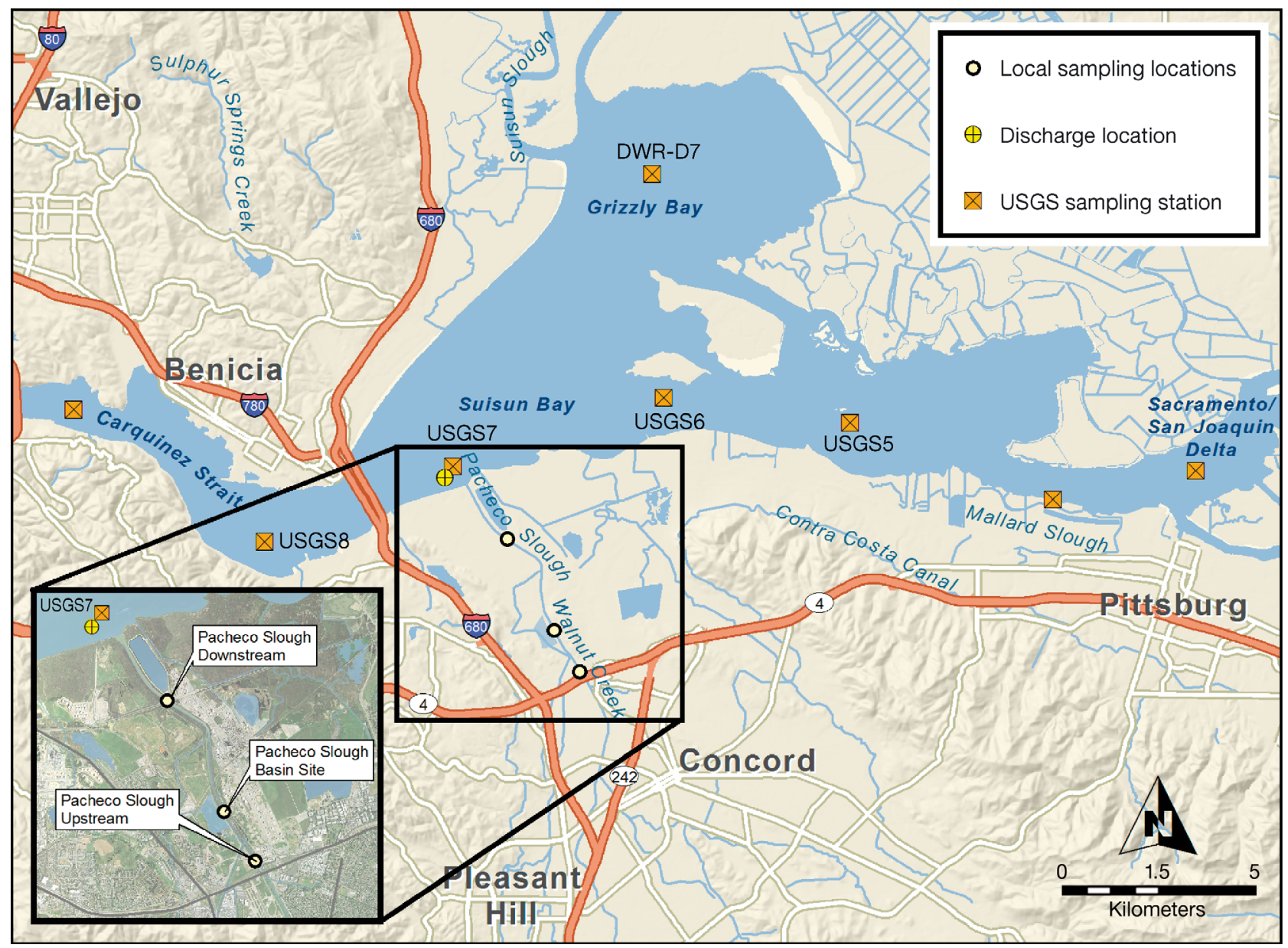

Fig. 1. Location of Pacheco Slough and USGS sampling stations in Suisun Bay. Inset with downstream, basin and upstream sites on Pacheco Slough as well as sampling site USGS7 at the entrance to the Slough

watershed is the larger of the 2. During the study period, the estimated inflow from Walnut Creek was about $132 \times 10^{6} \mathrm{ld}^{-1}$; Grayson Creek contributed only a small portion of that flow.

In the summer of 2012, CCCSD shut down its outfall and directed its effluent into its holding basin, from where it overflowed into Pacheco Slough at an average rate of $148 \times 10^{6} \mathrm{ld}^{-1}$. In addition to the basin, Pacheco Slough was sampled at 2 sites, one upstream from the basin overflow (hereafter upstream), and the other downstream of the overflow (hereafter downstream, Fig. 1). The downstream site was impacted by the effluent flow and tidal action, whereas the upstream site was not and therefore served as the control site. Surface samples were collected from all 3 sites on a weekly basis during slack, low-tide for chlorophyll a ( $\mathrm{chl}$ a), dissolved inorganic nutrients $\left(\mathrm{NH}_{4}{ }^{+}, \mathrm{NO}_{3}{ }^{-}\right.$, phosphorus [P]), dissolved oxygen, $\mathrm{pH}$, temperature, and phytoplankton community composition from 23 August through 11 October 2012 while the basin was overflowing into the slough. The same parameters were also sampled in the effluent going into the basin.

Dissolved oxygen, $\mathrm{pH}$ and temperature were measured immediately after sample collection using a HQ 40d Multi Auto Analyzer (Hach). The analyzer was calibrated before each sampling event following Method 10360 (Hach Company 2011). Salinity was measured using Method 2520 B in Eaton et al. (2005). Turbidity was measured using Method 180.1 (US EPA 1983).

The concentration of chl a was determined according to Parsons et al. (1984). Briefly, water was collected in a high density polyethylene (HDPE) bottle wrapped in aluminum foil, placed on ice, and transported to the lab where it was filtered in duplicate onto $25 \mathrm{~mm}$ Whatman GF/F filters. Filters were extracted for $4 \mathrm{~h}$ in the dark at $4^{\circ} \mathrm{C}$ in $90 \%$ acetone before being placed in a tissue grinder and macerated for $1 \mathrm{~min}$ at $500 \mathrm{rpm}$. Samples were transferred 
to a centrifuge tube via several rinses of the tissue grinder. Following centrifugation, total sample volume was adjusted to $10 \mathrm{ml}$ with $90 \%$ acetone, and chl a was measured fluorometrically using a Turner Fluorometer 10-AU (Turner Designs).

Samples for nutrient analysis were filtered through $0.7 \mu \mathrm{m}$ pore size GF/F filters prior to analysis. No effort was made in the present study to separate the concentration of $\mathrm{NH}_{4}{ }^{+}$from that of un-ionized ammonia $\left(\mathrm{NH}_{3}\right)$, which is toxic at relatively low concentrations (Källqvist \& Svenson 2003). The concentration of ammonia as a fraction of the total ammonia pool $\left(\mathrm{NH}_{4}{ }^{+}+\mathrm{NH}_{3}\right)$ is typically below $1 \%$ at $\mathrm{pH} 7$ and below $2 \%$ at pH 8 (Collos \& Harrison 2014), therefore of minor concern in the present investigation. Due to the wide range of $\mathrm{NH}_{4}{ }^{+}$concentrations in the present investigation, 2 different methods for measurements were used to eliminate error due to non-linearity. Low concentrations of $\mathrm{NH}_{4}{ }^{+}$were analyzed using the phenol hypochlorite colorimetric method (Solorzano 1969), and high concentrations of $\mathrm{NH}_{4}{ }^{+}$were analyzed using the acidimetric Method $4500 \mathrm{NH}_{3}$ B.C (Eaton et al. 2005). $\mathrm{NO}_{3}{ }^{-}$was analyzed colorimetrically using Method 418.D (Eaton et al. 2005). Dissolved P was analyzed colorometrically according to Parsons et al. (1984).

Samples for phytoplankton composition were preserved with $2 \mathrm{ml}$ of Lugol's solution per $200 \mathrm{ml}$ sample. Samples were filtered onto a $0.2 \mu \mathrm{m}$ polycarbonate membrane (Nuclepore) and enumerated using a Leica DMLB compound microscope according to McNabb (1960) as described in Beaver et al. (2013). Briefly, at least 400 natural units (colonies, filaments, and unicells) were enumerated to the lowest possible taxonomic level from each sample. The abundance of common taxa was estimated by random field counts. Rare taxa were quantified by scanning a transect of the filter. In the case of rare, large taxa, half of the filter was scanned and counted at a lower magnification. Cell volumes (biovolumes) were estimated by applying the geometric shapes that most closely matched the cell shape (Hillebrand et al. 1999). Biovolume calculations were based on measurements of 10 organisms per taxon for each sample where possible. Mean biovolume values were computed for any sampling event that included duplicate samples. Biovolume data corrected for occurrence of large vacuoles was used as a surrogate for cell biomass (Strathmann 1967).

Samples for phytoplankton enumeration, chl $a$, salinity, temperature, and turbidity were also collected on 17 September from United States Geological Survey (USGS) Stns USGS6, USGS7, USGS8, and
DWR-D7 in Suisun Bay using a zodiac boat (see Fig. 1 for locations). These samples were preserved and analyzed as described above. Data from Stns USGS6, USGS7, and USGS 8 were used as a point of comparison with the 3 sites sampled in the present study. The same data were measured at Stns USGS6, USGS7, USGS8, and DWR-D7 by the USGS on 11 September and are available online (http://sfbay. wr.usgs.gov/access/wqdata).

\section{RESULTS}

Effluent water discharged into the basin was characterized by low salinity and turbidity but very high dissolved nutrient concentrations (Table 1). $\mathrm{NH}_{4}{ }^{+}$ was the principal nitrogen source with an average concentration of $1931 \pm 118 \mu \mathrm{mol} \mathrm{l^{-1 }}$, followed by $\mathrm{NO}_{3}{ }^{-}$with a concentration of $34 \pm 8 \mu \mathrm{mol} \mathrm{l}^{-1}$. The $\mathrm{P}$ concentration was $81 \pm 19 \mu \mathrm{mol} \mathrm{l}^{-1}$ (Table 1 ).

The basin had very similar water quality characteristics to the effluent water in terms of dissolved oxygen, $\mathrm{pH}$, salinity, and turbidity (Tables $1 \& 2$ ). The upstream location was fairly similar to the basin with respect to salinity, but turbidity was lower (Table 2). The downstream location differed from the upstream location in 2 important ways. First, salinity was higher $(3.6 \pm 3.6$ vs. $0.6 \pm 0.05)$, and turbidity was an order of magnitude higher $(27 \pm 11$ vs. $2 \pm 0.5$ nephelometric turbidity units [NTU]). The higher salinities and turbidities of the downstream location were indicative of the degree of mixing between Suisun Bay and Pacheco Slough water over the tidal cycle. In Suisun Bay, salinity was $11 \pm 3$ and turbidity was $26 \pm 7$ NTU (Table 2).

Chl a concentrations varied by an order of magnitude in the basin, from 40 to $400 \mu \mathrm{g} \mathrm{chl} \mathrm{a}{ }^{-1}$ (Fig. 2A). Concentrations of chl a downstream were also variable but lower than in the basin, ranging from 5 to $120 \mu \mathrm{g} \mathrm{chl} \mathrm{a} \mathrm{l}^{-1}$ (Fig. 2A). Concentrations upstream were the lowest, and ranged from 1 to $5 \mu \mathrm{g} \mathrm{chl} \mathrm{a} \mathrm{l^{-1 }}$

Table 1. Effluent water-quality parameters (mean $\pm \mathrm{SD}, \mathrm{n}=47$ )

\begin{tabular}{|lc|}
\hline Parameter & Concentration \\
\hline Dissolved oxygen $\left(\mathrm{mg} \mathrm{l}^{-1}\right)$ & $7.5 \pm 1.7$ \\
$\mathrm{pH}$ & $7.3 \pm 0.1$ \\
Turbidity $(\mathrm{NTU})$ & $3.9 \pm 1.1$ \\
Salinity & $0.5 \pm 0.03$ \\
$\mathrm{NH}_{4}^{+}\left(\mu \mathrm{mol} \mathrm{l}^{-1}\right)$ & $1931 \pm 118$ \\
$\mathrm{NO}_{3}^{-}\left(\mu \mathrm{mol} \mathrm{l}^{-1}\right)$ & $34 \pm 8$ \\
$\mathrm{P}(\mu \mathrm{mol} \mathrm{l}$ & -1 \\
$\mathrm{~N}: \mathrm{P}$ ratio $(\mathrm{mol}: \mathrm{mol})$ & $81 \pm 19$ \\
\end{tabular}


Table 2. Basin, upstream, downstream and bay water-quality parameters $($ mean $\pm \mathrm{SD})$. DO: dissolved oxygen

\begin{tabular}{|lcccc|}
\hline Parameter & $\begin{array}{c}\text { Basin } \\
(\mathrm{n}=11)\end{array}$ & $\begin{array}{c}\text { Upstream } \\
(\mathrm{n}=11)\end{array}$ & $\begin{array}{c}\text { Downstream } \\
(\mathrm{n}=11)\end{array}$ & $\begin{array}{c}\text { Suisun Bay } \\
(\mathrm{n}=3)\end{array}$ \\
\hline $\mathrm{DO}\left(\mathrm{mg} \mathrm{l}^{-1}\right)$ & $7.5 \pm 1.7$ & $6.2 \pm 2$ & $5.8 \pm 2$ & $8.8 \pm 0.05$ \\
$\mathrm{pH}$ & $7.6 \pm 0.2$ & $7.7 \pm 0.2$ & $7.6 \pm 0.1$ & $7.5 \pm 0.06$ \\
Turbidity (NTU) & $5.4 \pm 1.7$ & $2.0 \pm 0.5$ & $26.6 \pm 11$ & $25.5 \pm 7$ \\
Salinity & $0.5 \pm 0.03$ & $0.6 \pm 0.05$ & $3.6 \pm 3.6$ & $11 \pm 3$ \\
Temperature $\left({ }^{\circ} \mathrm{C}\right)$ & $23 \pm 2.3$ & $20.5 \pm 1.6$ & $20.6 \pm 2.3$ & $19.3 \pm 0.5$ \\
\hline
\end{tabular}

would be predicted based on nutrient concentrations (Fig. 2).

The basin phytoplankton community evidenced biomass maxima occurring on 5 and 18 September and 5 October (Fig. 2A). The basin phytoplankton biomass maximum was dominated by chlorophytes on 5 September, giving way to a community dominated by euglenophytes on 18 September and back to chlorophytes on 5 October (Fig. 3A). While chloro-

(Fig. 2A). Despite vigorous phytoplankton growth, a high rate of effluent inflow to the basin prevented nutrients from becoming depleted; $\mathrm{NH}_{4}{ }^{+}$concentrations varied from 1671 to $2000 \mu \mathrm{mol} \mathrm{l^{-1 }}$ (Fig. 2B). Concentrations downstream varied from 150 (at the end of the time course) to $1350 \mu \mathrm{mol} \mathrm{l}^{-1}$ (Fig. 2B). Upstream, $\mathrm{NH}_{4}{ }^{+}$concentrations varied from 1 to $5 \mathrm{\mu mol} \mathrm{l}^{-1}$ (Fig. 2B). Concentrations of $\mathrm{NO}_{3}{ }^{-}$were greatest downstream, varying from 12 to $>80 \mu \mathrm{mol} \mathrm{l}^{-1}$, followed by the upstream location at 31 to $50 \mu \mathrm{mol} \mathrm{l}^{-1}$, and the basin where concentrations ranged between 5 and $30 \mu \mathrm{mol} \mathrm{l}^{-1}$ (Fig. 2C). Concentrations of P were greatest in the basin at 25 to $52 \mu \mathrm{mol} \mathrm{l}^{-1}$, followed by downstream at 6 to $38 \mu \mathrm{mol} \mathrm{l}^{-1}$, while upstream concentrations ranged from 2 to $5 \mu \mathrm{mol} \mathrm{l}^{-1}$, similar to the $\mathrm{NH}_{4}{ }^{+}$concentrations (Fig. 2D). At all 3 sites, chl a concentrations were much lower than that which
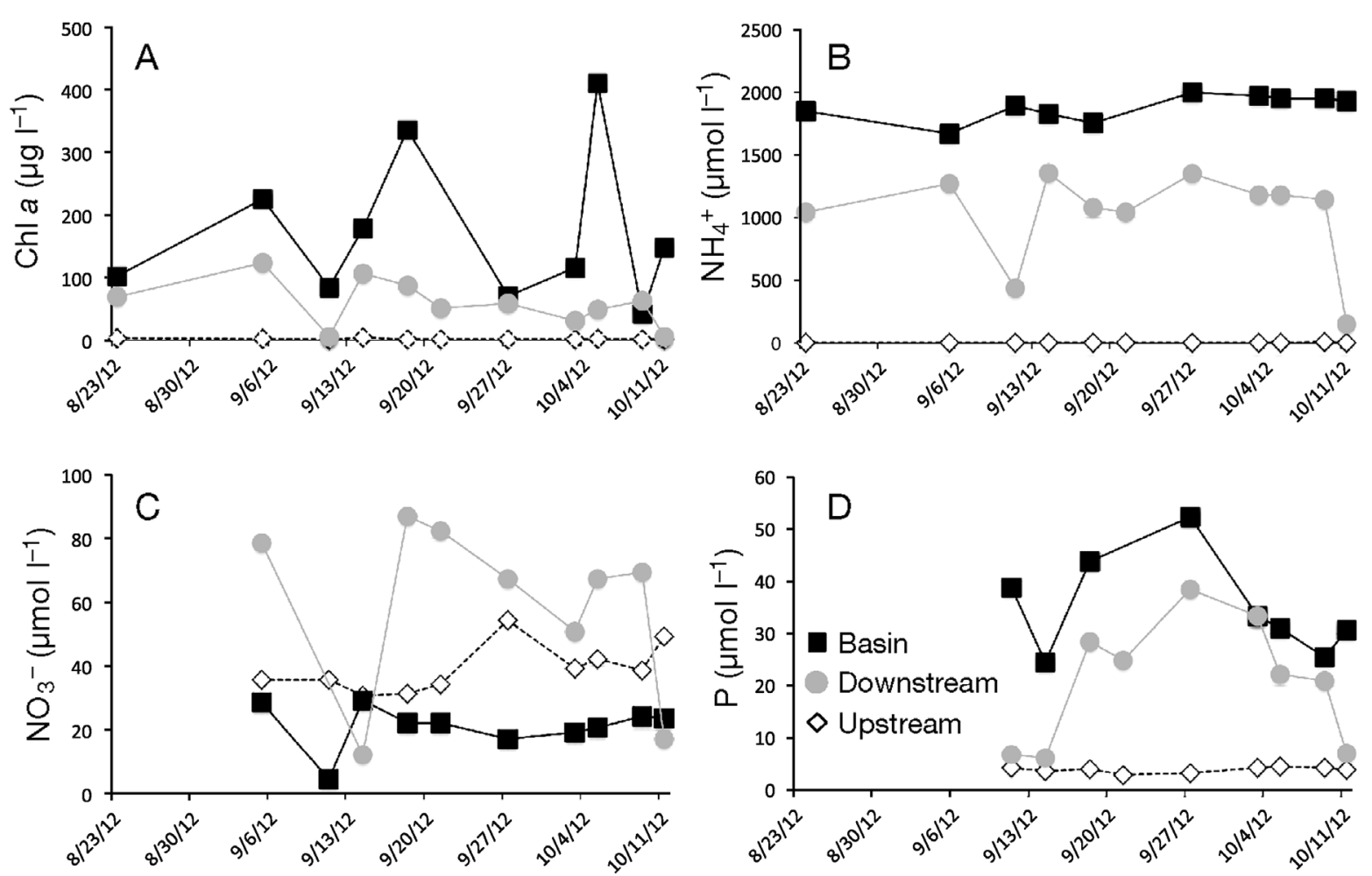

Fig. 2. Time course of (A) chl $a_{1}$ (B) $\mathrm{NH}_{4}{ }^{+},(\mathrm{C}) \mathrm{NO}_{3}{ }^{-}$, and (D) phosphorus concentration in the basin, downstream, and upstream

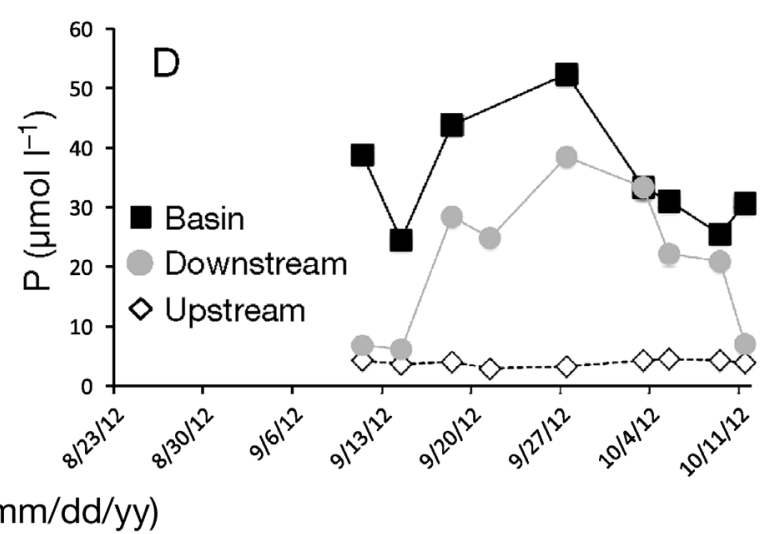

phytes and euglenophytes dominated the community composition based on biomass, they also dominated based on numerical abundance (Fig. 3B). In contrast to the basin, phytoplankton community composition based on biomass was dominated by diatoms at the downstream location (Fig. 3C). Although cryptophytes (and to a lesser degree, chlorophytes) became numerically important towards the end of the time course, contributing nearly $70 \%$ of phytoplankton community abundance on the last sampling day (Fig. 3D), they contributed $<10 \%$ to phytoplankton community composition on a biomass basis (Fig. 3C). Similar to the downstream community, the upstream phytoplankton community biomass was dominated by diatoms, with the exception of 9 October when biomass was co-dominated by diatoms and chlorophytes (Fig. 3E). Chlorophytes, cryptophytes, and to 

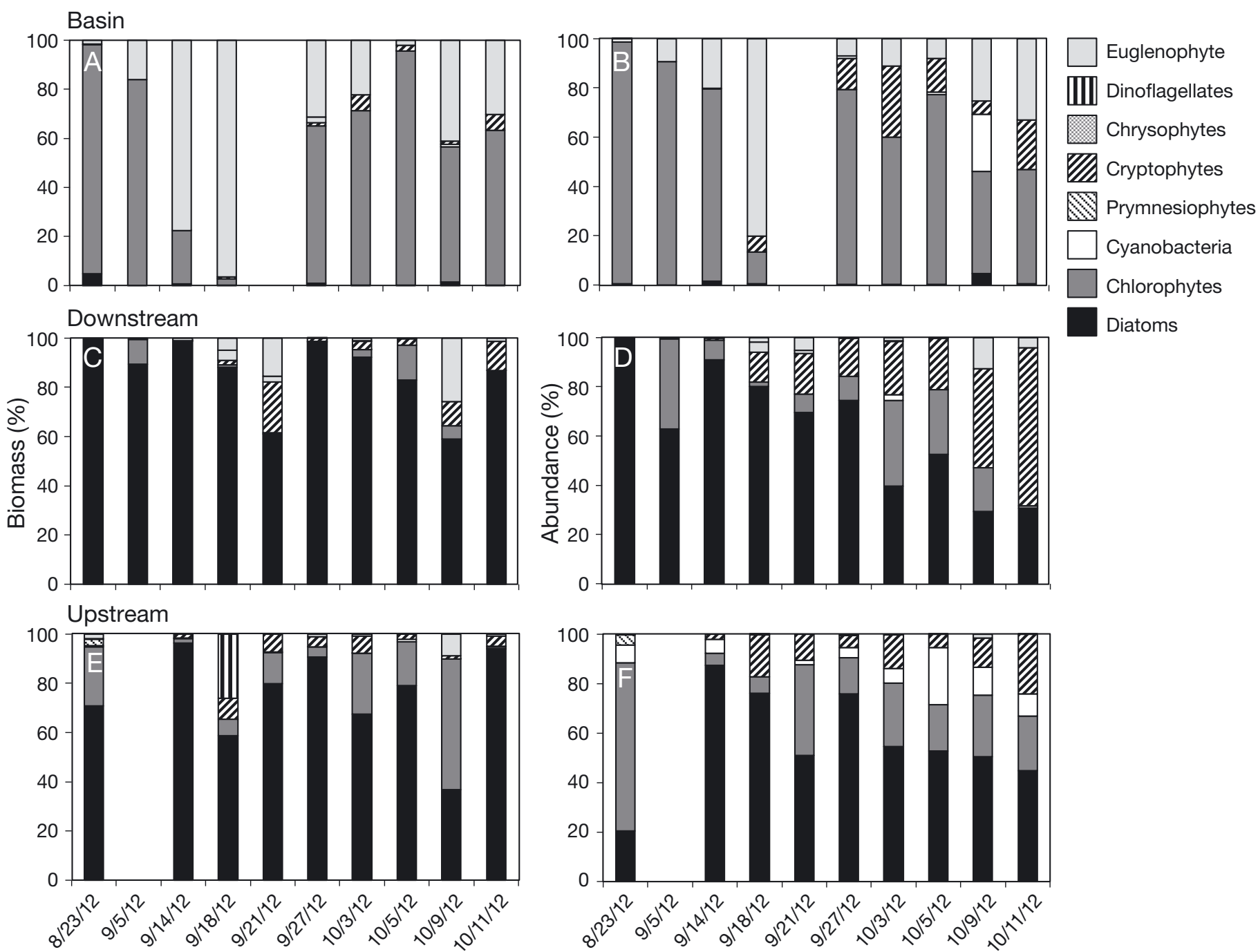

Fig. 3. Percent biomass and percent abundance of phytoplankton taxa over time in $(A, B)$ the basin, $(C, D)$ downstream, and $(\mathrm{E}, \mathrm{F})$ upstream. Dates are $\mathrm{mm} / \mathrm{dd} / \mathrm{yy}$

a lesser degree cyanobacteria, comprised a much greater share of community composition based on abundance compared with biomass at the upstream location (Fig. 3E,F).

Changes in phytoplankton species composition in the basin were driven by a succession of 3 different genera (Fig. 4). The maximum on 5 September was dominated by the chlorophyte Sphaerocystis sp., the maximum on 18 September was co-dominated by the euglenophytes Lepocinclis tripteris and Phacus sp., while the maximum on 5 October was dominated by the chlorophyte Gloeococcus minor (Fig. 4A-C). Downstream, peaks in chl a occurred on 5 and 14 September and 9 October and were dominated by the centric diatoms Cyclotella sp., Cyclotella scaldensis, and a mixed diatom-cryptophyte Rhodomonas sp. community, respectively (Fig. 5A-C). Upstream, peaks in chl $a$ biomass $\left(3.4,2.6\right.$, and $4.8 \mu \mathrm{g} \mathrm{chl} \mathrm{a} \mathrm{^{-1 } )}$ occurred on 23 August, 14 September, and 5 October, and were dominated by a chlorophyte from the Volvocales order, co-dominated by the diatoms Nitzschia spp. and Fragilaria spp., and Navicula vanhoeffenii and Cocconeis placentula, respectively (Fig. 6A-C).

To investigate whether the $\mathrm{NH}_{4}{ }^{+}$tolerant diatom species in Pacheco Slough were unique, we compared the composition of the diatom communities at the downstream and upstream location in Pacheco Slough with that in Suisun Bay at Stns USGS6, USGS7, USGS8 and DWR-D7 on 17 September 2012.

Of the 25 diatom species identified in Suisun Bay, and the 29 species identified at the downstream location in Pacheco Slough, 9 species overlapped (Table 3). These included Actinocyclus sp., Aulacoseira sp., Cyclotella sp., C. scaldensis, Cocconeis placentula, Nitzschia sp., Thalassiosira spp., T. eccentrica and 

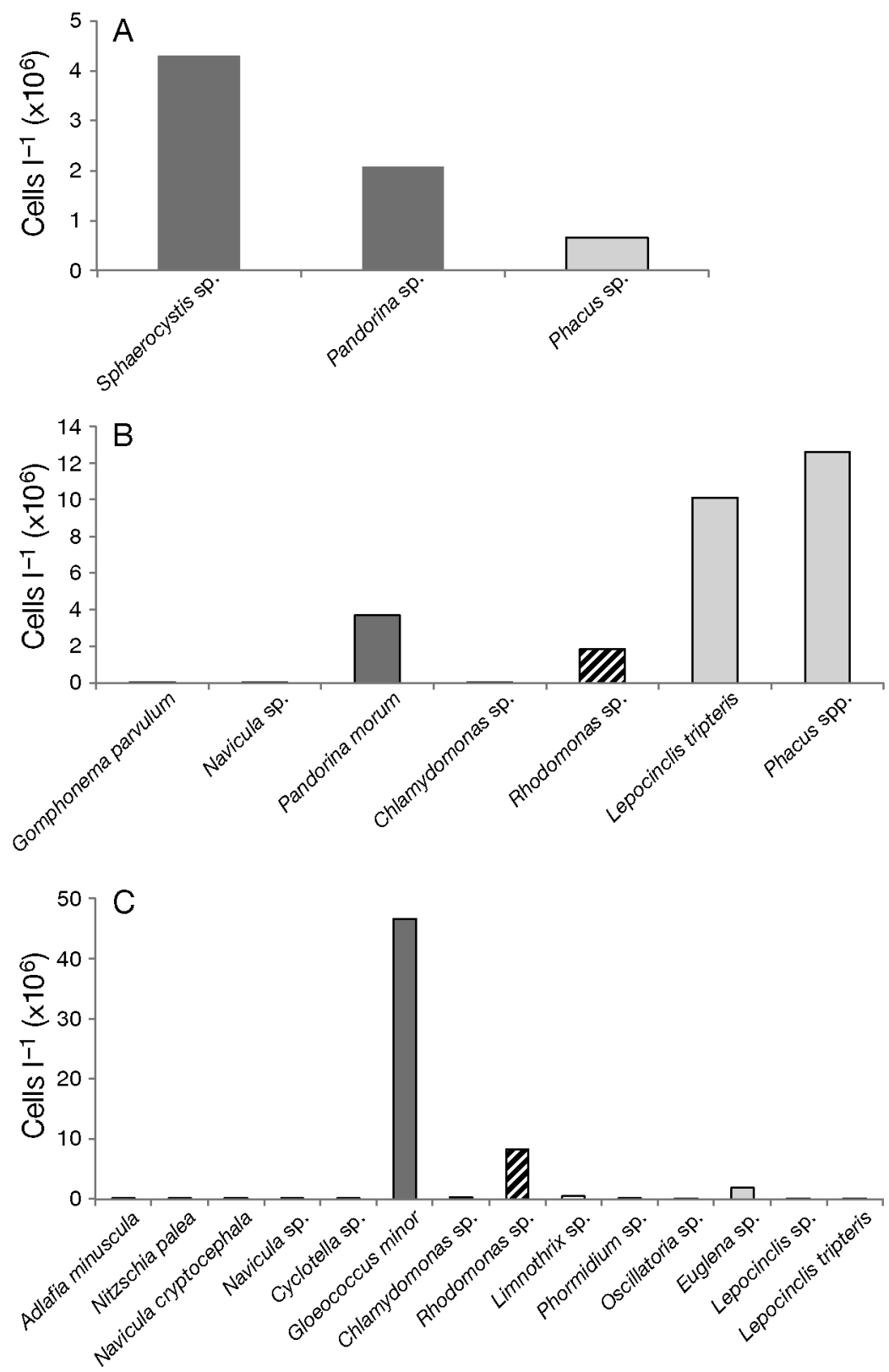

Fig. 4. Phytoplankton species composition during 3 separate biomass maxima in the basin occurring on (A) 5 September, (B) 18 September, and (C) 5 October 2012. Black bars: diatoms; grey bars: chlorophytes; stippled bars: cryptophytes; white bars: cyanobacteria; light grey bars: euglenophytes
Of the 28 diatom species identified at the upstream site, 9 overlapped with the downstream site. These included, as mentioned, Cyclotella sp. and C. placentula, and Bacillaria paxillifer, Geissleria decussis, Gomphonema parvulum, Nitzschia spp., Nitzschia archibaldii, $N$. palea and Rhoicosphenia abbreviata. Of these, G. parvulum and N. palea also occurred in the basin (Table 3). Several diatom species present at the upstream site were not present in the basin, downstream, or in Suisun Bay. These included Amphora minutissima, Fragilaria capucina, F. crotonensis, Pleurosira laevis and Stephanocyclus meneghiniana (Table 3).

The chlorophyll concentration in Suisun Bay was only $2.8 \pm 0.7 \mu g \mathrm{l}^{-1}$, and with above-normal incursions of Suisun Bay water coinciding with the spring tides, the downstream community evidenced biomass minima on 11 September and 11 October (Figs. 2 \& 7). On these dates, low-chlorophyll Suisun Bay water pushed the community growing at the downstream location further upstream; the chl a concentration downstream was restored the following sampling event when the tide started to retreat (Figs. $2 \& 7$ ).

Mean chl $a$ and $\mathrm{NH}_{4}{ }^{+}$concentrations were greatest in the basin, followed by the downstream site, with Suisun Bay and the upstream site 30 to 80 times lower (Fig. 8A,B). Similarly, mean P concentrations were 5 to 9 times greater at the basin and downstream sites compared with Suisun Bay and the upstream site (Fig. 8A). In contrast, the mean $\mathrm{NO}_{3}{ }^{-}$concentration was greater at the downstream site (59 \pm $27 \mu \mathrm{mol} \mathrm{\textrm {l } ^ { - 1 }}$ ) compared with the basin $\left(39 \pm 7 \mu \mathrm{mol} \mathrm{l^{-1 }}\right)$, Suisun Bay $(28.8 \pm$ $\left.0.5 \mu \mathrm{mol} \mathrm{l}^{-1}\right)$, or upstream $\left(21 \pm 7 \mathrm{~mol} \mathrm{l}^{-1}\right)$.

Tryblionella debilis. Of the overlapping species, Aulacoseira sp., Actinocyclus sp., C. scaldensis, Thalassiosira sp., T. eccentrica and Tryblionella sp. did not occur in measurable abundance upstream or in the basin. Two of the overlapping species, C. placentula and Cyclotella spp., were present at the upstream station (possibly also a Nitzschia sp.). The genera Stephanodiscus and Pleurosigma commonly occurred in the Suisun Bay samples but did not occur in Pacheco Slough or in the basin (Table 3).
This could potentially be because residence times at the downstream location were long enough for $\mathrm{NO}_{3}{ }^{-}$ to accumulate from these sources, or $\mathrm{NO}_{3}{ }^{-}$could have been produced at the downstream location by nitrifying bacteria. Using the geometric mean specific nitrification rate $\left(0.162 \mathrm{~d}^{-1}\right)$ to calculate $\mu \mathrm{mol} \mathrm{NO}_{3}{ }^{-} \mathrm{l}^{-1}$ produced per $\mu \mathrm{mol} \mathrm{NH}_{4}^{+} \mathrm{l}^{-1} \mathrm{~d}^{-1}$ according to Yool et al. (2007), we obtained a potential production of $165 \pm$ $61 \mu \mathrm{mol} \mathrm{NO}{ }_{3}^{-} \mathrm{l}^{-1} \mathrm{~d}^{-1}$ at the downstream location, which could explain the higher concentrations observed there. 
Despite high potential $\mathrm{NO}_{3}{ }^{-}$production rates and concentrations, the mean dissolved $\mathrm{N}: \mathrm{P}$ ratio was largely driven by the high $\mathrm{NH}_{4}{ }^{+}$concentration in the basin and downstream, averaging $58 \pm 14$ and $65 \pm$ 60, respectively. In Suisun Bay and upstream, where
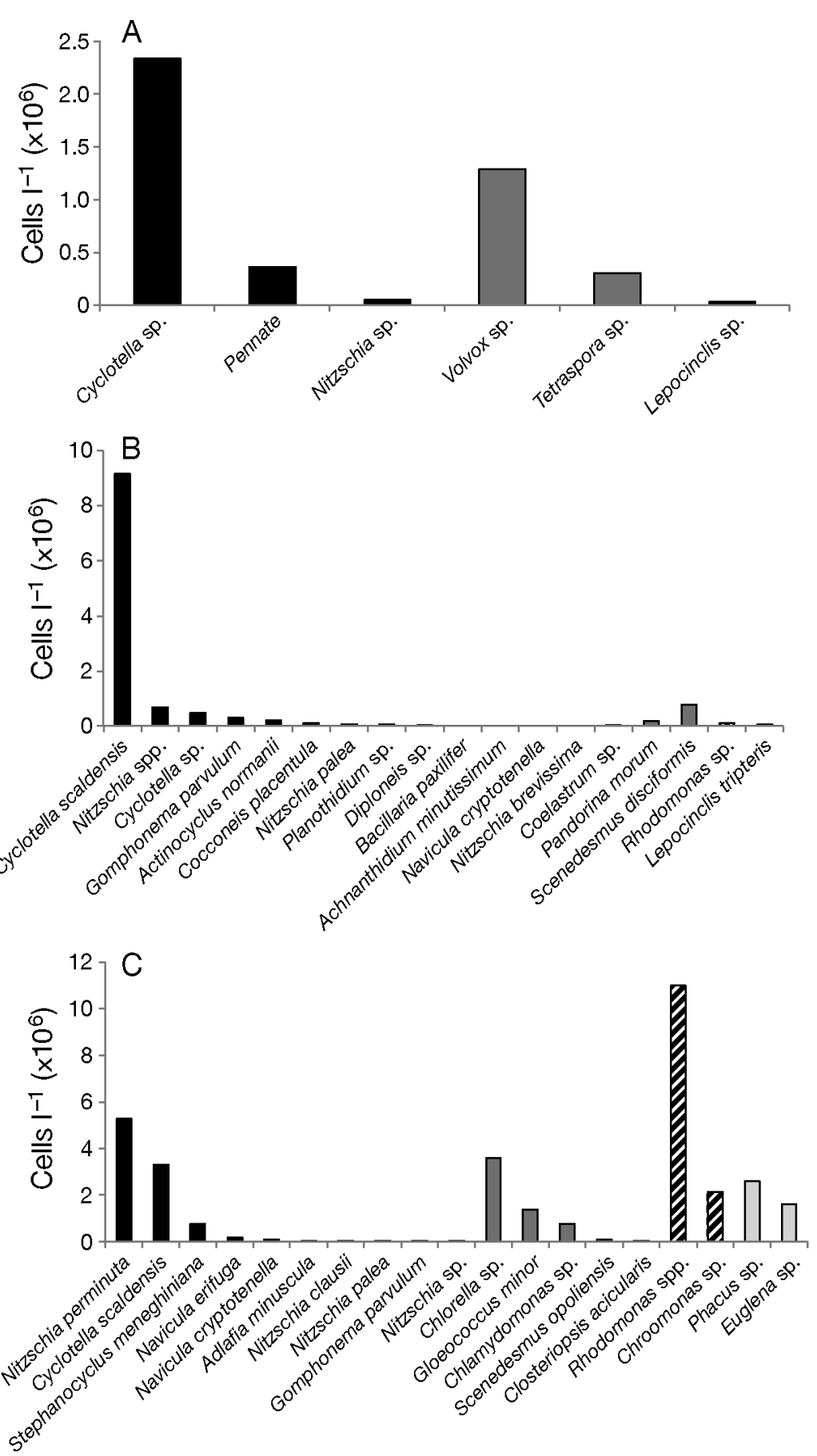

Fig. 5. Phytoplankton species composition during 3 separate biomass maxima occurring downstream on (A) 5 September, (B) 14 September, and (C) 9 October 2012. Black bars: diatoms; grey bars: chlorophytes; stippled bars: cryptophytes; light grey bars: euglenophytes
$\mathrm{NO}_{3}{ }^{-}$was the dominant $\mathrm{N}$ source, the $\mathrm{N}: \mathrm{P}$ ratio was $6.9 \pm 0.6$ and $11 \pm 2$, respectively (Fig. 8A). Consistent with the switch from $\mathrm{NH}_{4}{ }^{+}$to $\mathrm{NO}_{3}{ }^{-}$as the dominant $\mathrm{N}$ source, the $\mathrm{NH}_{4}{ }^{+}: \mathrm{NO}_{3}{ }^{-}$ratio was $122 \pm 115$ and $26 \pm$ 32 in the basin and downstream, respectively, versus $0.16 \pm 0.03$ and $0.08 \pm 0.03$ in Suisun Bay and upstream, respectively (Fig. 8A). In the basin, chlorophytes were most abundant, whereas diatoms were most abundant downstream, in Suisun Bay, and upstream (Fig. 8B). Cyanobacteria were approximately the same at all 3 sites. The ratio of diatom biomass to the biomass of chlorophytes + euglenophytes + cyanobacteria + cryptophytes (i.e. diatoms:others) was $0.02 \pm 0.02$ in the basin, $48 \pm 87$ downstream, $9.5 \pm 1$ in Suisun and $9.5 \pm 8$ upstream (Fig. 8B). The large ratio of diatoms:others at the downstream site, and the large variability in this ratio, was driven by a large increase in the ratio of diatom:others biomass at the beginning of the time course (data not shown).

\section{DISCUSSION}

Phytoplankton biomass at the downstream location in Pacheco Slough $(59 \pm 37 \mu \mathrm{g}$ chl a $\left.1^{-1}\right)$ was 30 -fold greater than the Suisun Bay $\left(2.8 \pm 0.7 \mu \mathrm{g} \mathrm{chl} \mathrm{a}^{-1}\right)$ or the upstream $(2.1 \pm$ $1 \mu \mathrm{g} \mathrm{chl} \mathrm{a} \mathrm{l}^{-1}$ ) end-members, suggesting that the basin overflow into the Slough either delivered a great deal of phytoplankton biomass to this location, or that the nutrients delivered via the wastewater effluent resulted in promoting the growth of the phytoplankton already present at this location. Analysis of phytoplankton community composition at the downstream site compared with Suisun Bay demonstrated that the latter was true. The analysis also demonstrated that high concentrations of $\mathrm{NH}_{4}{ }^{+}$do not lead to a community that is substantially different from the seed community. Diatoms, as a fraction of total community composition, increased dramatically lead by the centric diatom Cyclotella scaldensis. This species, together with diatoms such as Thalassiosira eccentrica, Thalassiosira sp., Actinocyclus sp., and Aulacoseira sp. were present at relatively high abundances in Suisun Bay at the time of the study. Moreover, these species were either not present, or present in low concentrations at the upstream site in Pacheco Slough or in the basin. 

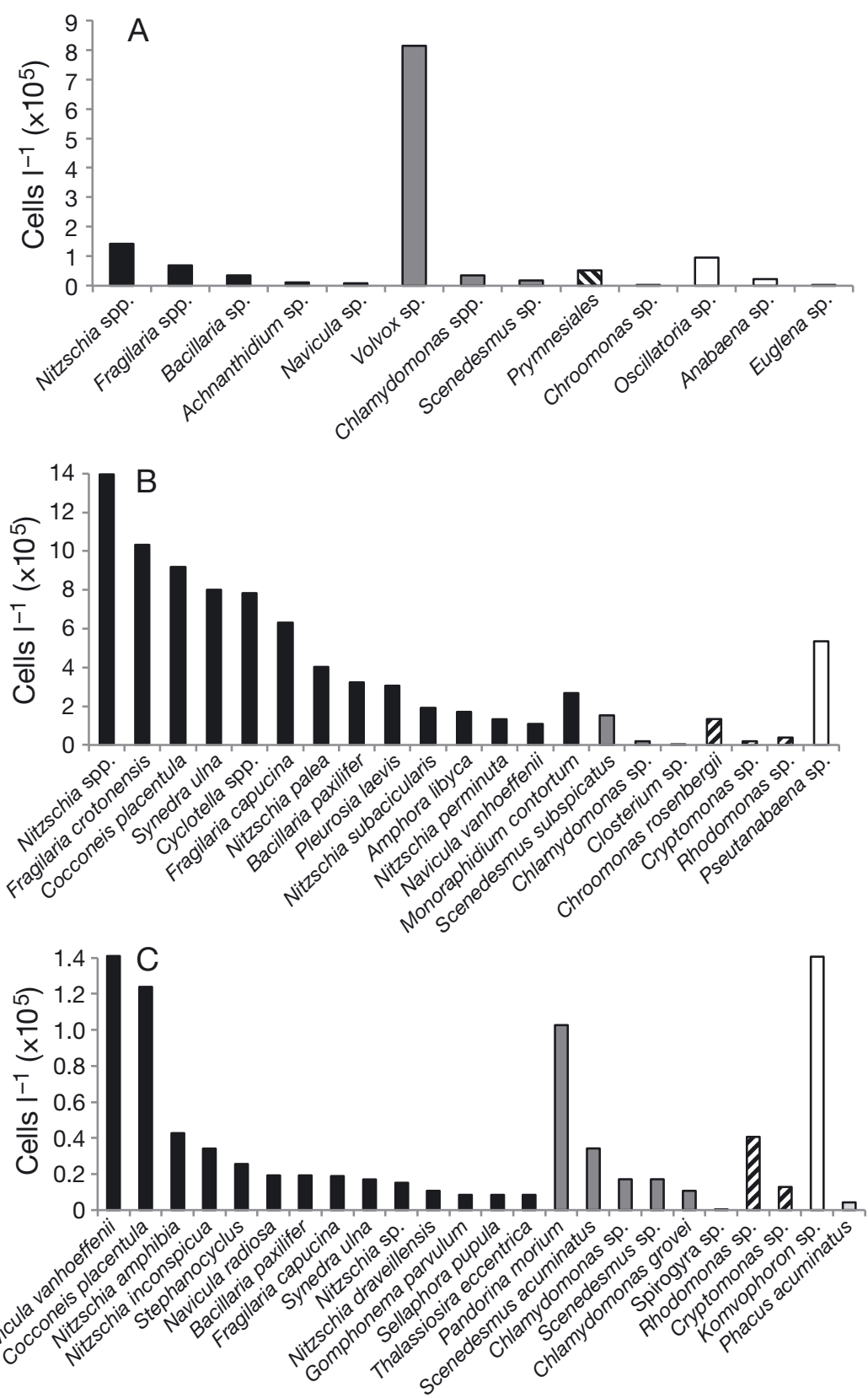

Fig. 6. Phytoplankton species composition during 3 separate biomass maxima occurring upstream on (A) 23 August, (B) 14 September, and (C) 5 October 2012. Black bars: diatoms; grey bars: chlorophytes; stippled bars: cryptophytes; white bars: cyanobacteria; light grey bars: euglenophytes

other phytoplankton species, demonstrating that diatoms are not more susceptible to inhibition of growth by $\mathrm{NH}_{4}{ }^{+}$than other taxa. Thirdly, conditions in Pacheco Slough were more favorable than in Suisun Bay, resulting in a several-fold increase in the diatom population. And lastly, conditions upstream in Pacheco Slough were not favorable for the growth of any phytoplankton despite high nutrient (particularly high $\mathrm{NO}_{3}^{-}$) concentrations. We will discuss each of these observations in turn.

In Suisun Bay, as well as other highnutrient coastal areas around the world, centric diatoms such as Cyclotella sp., Thalassiosira sp., Coscinodiscus sp., and Aulacoseira sp. are the most commonly observed bloom formers (Arthur \& Ball 1979, Ball \& Arthur 1979, Prasad et al. 1990, Lehman 1996, 2000, Collos et al. 2005). The genus Cyclotella has also been reported to dominate algal blooms in high-nutrient freshwater systems (Muylaert \& Sabbe 1996, Wehr \& Descy 1998, Mitrovic et al. 2008, Beaver et al. 2013). While these species have been reported to grow uninhibited in eutrophic estuaries at $\mathrm{NH}_{4}{ }^{+}$and $\mathrm{NO}_{3}{ }^{-}$concentrations approaching several hundred $\mu \mathrm{mol} \mathrm{l}^{-1}$ (Collos et al. 2005, Collos \& Harrison 2014), other investigators have questioned whether concentrations of $\mathrm{NH}_{4}{ }^{+}$as low as $30 \mu \mathrm{mol} \mathrm{l^{-1 }}$ near wastewater discharges negatively impact phytoplankton production (Thomas et al. 1974, MacIsaac et al. 1979, Glibert et al. 2011, Parker et al. 2012). Whereas $30 \mu \mathrm{mol} \mathrm{NH}_{4}^{+} \mathrm{l}^{-1}$ is high for a marine system, culture investigations demonstrate that negative impacts on phytoplankton growth and production by nutrients typically occur at much greater concentrations. For example, in a screen of freshly isolated phyto-

These results suggest that a seed population advected with the tide into Pacheco Slough from Suisun Bay was responsible for the high phytoplankton biomass observed there. Several interesting conclusions can be drawn from this observation. One is that estuarine diatoms that typically grow in the range of 0 to $20 \mu \mathrm{mol} \mathrm{l^{-1 }} \mathrm{NH}_{4}^{+}$can easily grow at concentrations approaching $1350 \mu \mathrm{mol} \mathrm{l}^{-1}$. Another is that the high $\mathrm{NH}_{4}{ }^{+}$conditions favored diatoms over plankton from California coastal water, Thomas et al. (1980) found no inhibition of photosynthesis or growth at concentrations varying from 5 to $200 \mu \mathrm{mol}$ $\mathrm{NH}_{4}{ }^{+} \mathrm{l}^{-1}$ in several diatoms.

In a recent review of phytoplankton $\mathrm{NH}_{4}{ }^{+}$tolerance thresholds, Collos \& Harrison (2014) reported that the optimal $\mathrm{NH}_{4}{ }^{+}$concentration for growth of diatoms in culture was on average $340 \mu \mathrm{mol} \mathrm{l}^{-1}$, and that growth inhibition (as defined by a reduction in growth 
Table 3. Diatom species composition on 17 September 2012 at Stns DWR-D7, USGS6, USGS7, and USGS8 in Suisun Bay, compared with downstream in Pacheco Slough on 14, 18, 21, and 27 September (D914, D918, D921, D927, respectively), upstream in Pacheco Slough on 14, 18, 21, and 27 September (U914, U918, U921, U927), and in the basin on 14, 18, and 27 September

(B914, B918, B927)

\begin{tabular}{|c|c|c|c|}
\hline DWR-D7 & USGS6 & USGS7 & USGS8 \\
\hline Cyclotella scaldensis & Thalassiosira eccentrica & Aulacoseira subarctica & Cyclotella scaldensis \\
\hline Thalassiosira spp. & Aulacoseira ambigua & Epithemia adnata & Thalassiosira spp. \\
\hline Cyclotella sp. & Achnanthidium minutissimum & Cyclotella scaldensis & Cyclotella sp. \\
\hline Stephanodiscus sp. & Cocconeis placentula & Cyclotella sp. & Stephanodiscus sp. \\
\hline Cocconeis placentula & Nitzschia sp. & Hantzschia sp. & Cocconeis placentula \\
\hline Navicula minuscula & Tryblionella sp. & Actinocyclus sp. & Navicula minuscula \\
\hline Tryblionella debilis & Asterionella formosa & Cocconeis placentula var. lineata & Tryblionella debilis \\
\hline Pleurosigma sp. & Epithemia sp. & Tryblionella navicularis & Pleurosigma sp. \\
\hline Aulacoseira sp. & Synedra ulna & Cymbella sp. & Aulacoseira sp. \\
\hline Actinoptychus senarius & Cyclotella scaldensis & Gyrosigma sp. & Actinoptychus senarius \\
\hline D914 & D918 & D921 & D927 \\
\hline Cyclotella scaldensis & Cyclotella scaldensis & Cyclotella scaldensis & Nitzschia archibaldii \\
\hline Nitzschia spp. & Nitzschia spp. & Nitzschia spp. & Cyclotella scaldensis \\
\hline Cyclotella spp. & Cyclotella spp. & Cyclotella spp. & Thalassiosira sp. \\
\hline Gomphonema parvulum & Melosira varians & Craticula halophila & Cyclotella sp. \\
\hline Actinocyclus normanii & Craticula buderi & Thalassiosira cf. eccentrica & Thalassiosira cf. eccentrica \\
\hline Cocconeis placentula & Gyrosigma wansbeckii & Nitzschia clausii & Bacillaria paxillifer \\
\hline Nitzschia palea & Actinocyclus sp. & Rhoicosphenia abbreviata & Nitzschia inconspicua \\
\hline Planothidium sp. & Gomphonema parvulum & Navicula tripunctata & Rhopalodia gibba \\
\hline Diploneis sp. & Geissleria decussis & Aulacoseira sp. & Craticula molesta \\
\hline Bacillaria paxillifer & Psammothidium sp. & Cocconeis placentula & Tryblionella granulata \\
\hline U914 & U918 & U921 & U927 \\
\hline Nitzschia spp. & Nitzschia spp. & Cocconeis placentula & Nitzschia cf. archibaldii \\
\hline Fragilaria crotonensis & Amphora minutissima & Amphora minutissima & Cocconeis placentula \\
\hline Cocconeis placentula & Fragilaria capucina & Fragilaria capucina & Nitzschia spp. \\
\hline Synedra ulna & Cocconeis pediculus & Cyclotella sp. & Synedra acus \\
\hline Cyclotella spp. & Gomphonema parvulum & Nitzschia acicularis & Melosira varians \\
\hline Fragilaria capucina & Cyclotella spp. & Nitzschia perminuta & Stephanocyclus meneghiniana \\
\hline Nitzschia palea & Craticula halophila & Nitzschia reversa & Sellaphora pupula \\
\hline Bacillaria paxillifer & Geissleria decussis & Nitzschia sp. & Nitzschia draveillensis \\
\hline Pleurosira laevis & Rhoicosphenia abbreviata & Sellaphora pupula & Nitzschia palea \\
\hline Nitzschia subacicularis & Navicula vanhoeffenii & Surirella minuta & Fragilaria capucina \\
\hline B914 & B918 & & B927 \\
\hline Cyclotella sp. & Nitzschia palea & & Sellaphora pupula \\
\hline Gomphonema parvulum & Gomphonema parvulum & & Gomphonema parvulum \\
\hline Nitzschia palea & Gomphonema sp. & & Navicula cryptotenella \\
\hline
\end{tabular}

rate of $50 \%$ ) occurred on average at $750 \mu \mathrm{mol} \mathrm{l}^{-1}$. As noted by these authors, chlorophytes and cyanobacteria generally have greater $\mathrm{NH}_{4}{ }^{+}$tolerance thresholds than diatoms, and diatoms typically have greater tolerance thresholds than dinoflagellates (Collos \& Harrison 2014). There are notable exceptions to these thresholds for $\mathrm{NH}_{4}{ }^{+}$tolerance, as illustrated by the centric diatom Cyclotella sp. which can grow at a concentration of $3000 \mu \mathrm{mol} \mathrm{NH}{ }_{4}^{+} \mathrm{l}^{-1}$ in culture without experiencing growth inhibition (Pahl et al. 2012). Most importantly, these thresholds are far above the concentrations of $\mathrm{NH}_{4}{ }^{+}$occurring in Suisun Bay that have been suggested to place diatoms at a disadvantage relative to dinoflagellates and cyanobacteria
(Glibert 2010, Glibert et al. 2011), and to reduce their growth (Dugdale et al. 2007, Parker et al. 2012), suggesting that the changes in phytoplankton composition and growth observed in those investigations were due to factors other than $\mathrm{NH}_{4}{ }^{+}$concentration.

The present data also demonstrate that at nonlimiting concentrations, nutrient ratios are not good predictors of phytoplankton community composition. For example, Suisun Bay and the downstream location had similar salinities $(11 \pm 3$ and $4 \pm 3.6$, respectively) and turbidities (26 \pm 7 and $27 \pm 11$, respectively), but the downstream location had greater $\mathrm{NH}_{4}{ }^{+}$concentrations, $\mathrm{N}: \mathrm{P}$ ratios, and $\mathrm{NH}_{4}{ }^{+}: \mathrm{NO}_{3}{ }^{-}$ ratios than Suisun Bay. Phytoplankton biomass down- 


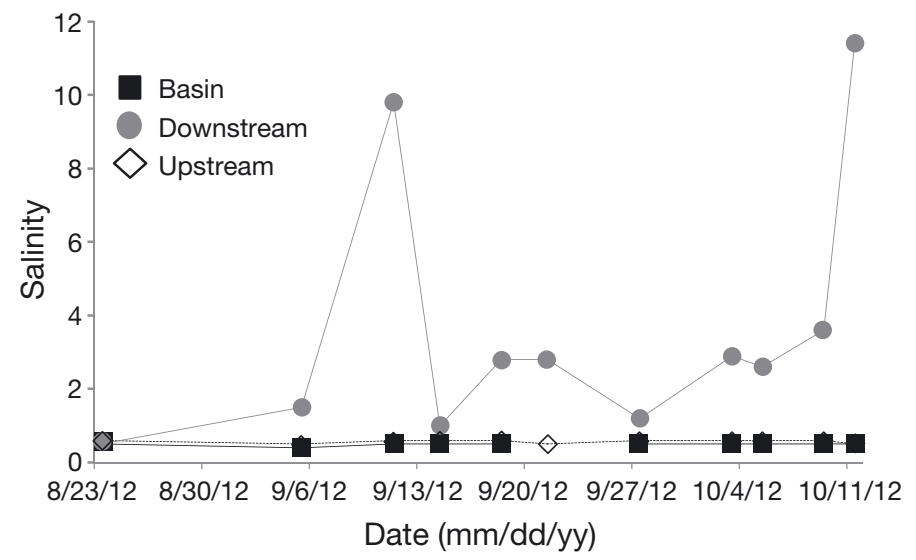

Fig. 7. Changes in salinity at slack tide at the 3 different sampling sites

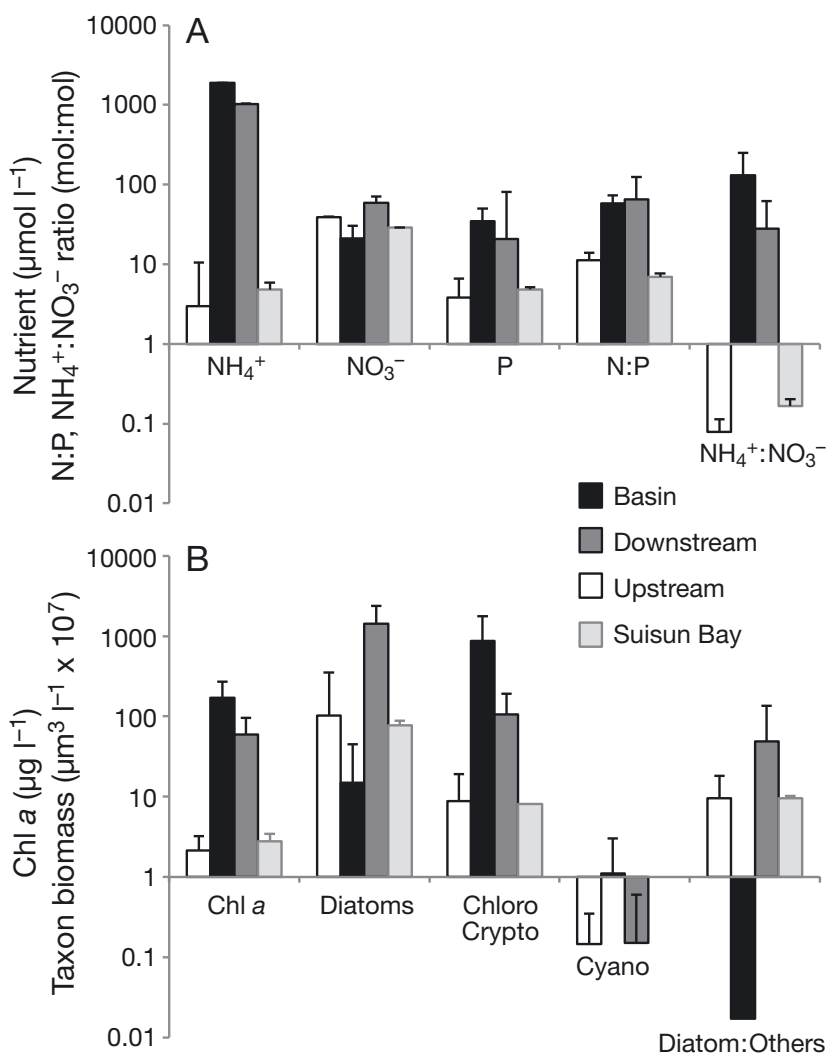

Fig. 8. Mean concentrations of (A) nutrients and ratios of $\mathrm{N}: \mathrm{P}$ and $\mathrm{NH}_{4}{ }^{+}: \mathrm{NO}_{3}{ }^{-}$, and (B) chl $a$, phytoplankton taxa, and ratios of diatoms to other phytoplankton taxa upstream, in the basin, downstream, and in Suisun Bay

stream was 30-fold greater than in Suisun Bay, but, despite dissimilar nutrient ratios, the taxonomic composition overlapped in terms of the ratio of diatoms:others (9.5 \pm 1 and $48 \pm 87$, respectively) as well as in the dominant phytoplankton species (i.e. C. scaldensis). Likewise, the upstream location and the basin had similar salinities $(0.6 \pm 0.05$ and $0.5 \pm$ 0.03 , respectively) and turbidities $(2 \pm 0.5$ and $5 \pm$ 1.7 NTU, respectively), but $\mathrm{NH}_{4}{ }^{+}$concentrations, $\mathrm{N}: \mathrm{P}$ ratios, and $\mathrm{NH}_{4}{ }^{+}: \mathrm{NO}_{3}{ }^{-}$ratios were greater in the basin than upstream. Phytoplankton biomass in the basin was 80-fold greater than upstream, but, contrary to the comparison between downstream and Suisun Bay, the taxonomic composition between upstream and the basin differed substantially as defined by the ratio of diatoms:others $(9.5 \pm 8$ vs. $0.02 \pm 0.02$, respectively) and the dominant phytoplankton species (Nitzchia and Fragilaria diatoms versus Lepocinclis and Phacus euglenophytes).

These observations can be reconciled if we consider that in the first example (Suisun Bay and downstream), the seeding populations between the 2 sites were similar, whereas in the second example (upstream and the basin), the seeding populations were very different; the basin was a semi-enclosed system most likely seeded by dormant algal spores from the sediments, whereas the upstream location was seeded by exchange with Walnut and Grayson Creeks.

Differences in seeding populations can also be used to argue for the divergence in population trajectories between downstream and the basin, despite similarly high N:P (58 \pm 14 and $65 \pm 60$, respectively) and $\mathrm{NH}_{4}{ }^{+}: \mathrm{NO}_{3}{ }^{-}(122 \pm 115$ and $26 \pm 32$, respectively) ratios in both locations. However, a number of factors besides the seeding population disparity could have acted to maintain divergent phytoplankton populations, including salinity, turbidity, turbulence (from tidal action), and temperature. The ability of diatoms to dominate environments that have high rates of flow, mixing, turbulence, and nutrient concentrations is well documented (Margalef 1978, Margalef et al. 1979, Smayda 1997, Smayda \& Reynolds 2001, Collos et al. 2005, Sarthou et al. 2005). But why did diatoms imported from Suisun Bay grow so much better when they entered Pacheco Slough given that Suisun Bay is also a high-nutrient, high-turbulence environment?

A significant decrease in water column depth, therefore an increase in the average irradiance, may have contributed to the increase in diatom abundance in Pacheco Slough over Suisun Bay. Average water column irradiance (integrated PAR/water column depth) calculated from PAR profiles at Stns USGS5, USGS6, USGS7 and USGS8 in Suisun in the month of September ranged from 6 to $50 \mu \mathrm{mol}$ photons $\mathrm{m}^{-2} \mathrm{~s}^{-1}$, and light attenuation coefficients ranged from 0.91 to $1.34 \mathrm{~m}^{-1}$ (data from USGS water quality monitoring program). Turbidity at these same stations ranged from 20 to 33 NTU, similar to Pacheco 
Slough $(27 \pm 11$ NTU). Going from Stn USGS7 in Suisun Bay (outside the entrance to Pacheco Slough) to Pacheco Slough, average irradiance increased from $45 \mu \mathrm{mol} \mathrm{m} \mathrm{m}^{-2} \mathrm{~s}^{-1}$ to $519 \mu \mathrm{mol} \mathrm{m} \mathrm{m}^{-2} \mathrm{~s}^{-1}$. It is likely that phytoplankton productivity and growth increased commensurately with the increase in irradiance, leading to the abnormally high chl a levels observed at the downstream location.

Given the higher mean irradiance levels in Pacheco Slough, it would be expected that the upstream phytoplankton community would attain a biomass level such that nutrients would essentially be depleted. Contrary to expectation, low chl a concentrations were coupled with $\mathrm{NO}_{3}{ }^{-}$concentrations of $39 \pm$ $8 \mu \mathrm{mol} \mathrm{l} \mathrm{l}^{-1}$ and $\mathrm{P}$ concentrations of $3.8 \pm 0.5 \mu \mathrm{mol} \mathrm{l}^{-1}$ (Fig. 8). The fact that neither $\mathrm{NO}_{3}{ }^{-}$nor $\mathrm{P}$ was drawndown upstream suggests that there was a micronutrient or trace metal that limited the upstream phytoplankton community. The limiting agent could have been supplied with the wastewater effluent, allowing the phytoplankton at the downstream location to grow. Alternatively, if the limiting agent did not affect $\mathrm{NH}_{4}{ }^{+}$assimilation, the phytoplankton at the downstream location could have been utilizing $\mathrm{NH}_{4}{ }^{+}$ exclusively, which was on average 300 -fold greater than upstream and is consistent with a general preference for $\mathrm{NH}_{4}{ }^{+}$over $\mathrm{NO}_{3}{ }^{-}$by phytoplankton (Cresswell \& Syrett 1979, Syrett 1981, 1988, Fernandez \& Cardenas 1989, Huppe et al. 1994, Berges et al. 1995, Hildebrand \& Dahlin 2000, He et al. 2004, Song \& Ward 2007).

In summary, we have demonstrated that diatoms are not particularly susceptible to atypically high $\mathrm{NH}_{4}{ }^{+}$concentrations and that they are not outcompeted by other taxa when $\mathrm{NH}_{4}{ }^{+}$is the main source of $\mathrm{N}$ available for growth. Diatom species composition and diversity overlapped in Suisun Bay and the downstream location, suggesting that phytoplankton seed composition was an important parameter with respect to the phytoplankton community that developed. The dominant phytoplankton species in this community was the centric diatom C. scaldensis, which also dominated the phytoplankton communities at several stations throughout Suisun Bay. In addition to high $\mathrm{NH}_{4}{ }^{+}$concentrations, relief from constant light limitation owing to a shallower water column (therefore increased irradiance) likely contributed to the relatively high biomass accumulation of C. scaldensis in Pacheco Slough compared with Suisun Bay. C. scaldensis thrived at $\mathrm{NH}_{4}{ }^{+}$concentrations as high as $1350 \mu \mathrm{mol} \mathrm{l}^{-1}$, suggesting that promoting diatom growth does not require decreasing $\mathrm{NH}_{4}{ }^{+}$concentrations as recently suggested (Dugdale et al. 2007, Glibert 2010, Parker et al. 2012). A more holistic understanding of how light, seed populations, turbidity, mixing, and residence time of water interact with available nutrients and trace metals is needed in order to understand the factors that govern phytoplankton growth in this region.

Acknowledgements. Many thanks to Tara Schraga for sharing PAR data from Suisun Bay. We also thank Tri Nguyen, Anita Setty, Salvador Rosales, Charles Burch, Jackeline Campos, James Wan and Ana Dias for help with laboratory analyses and field work. We gratefully acknowledge Jeff Miller and C. Walker for help with chl a analyses, and John $\mathrm{R}$. Beaver for all the help related to phytoplankton enumeration. We thank Velisa Parks for her assistance in preparing this manuscript.

\section{LITERATURE CITED}

Alpine AE, Cloern JE (1988) Phytoplankton growth rates in a light limited environment, San Francisco Bay. Mar Ecol Prog Ser 44:167-173

Alpine AE, Cloern JE (1992) Trophic interactions and direct physical effects control phytoplankton biomass and production in an estuary. Limnol Oceanogr 37:946-955

Arthur JF, Ball MD (1979) Factors influencing the entrapment of suspended material in the San Francisco BayDelta Estuary. In: TJ Conomos (ed) San Francisco Bay: the urbanized estuary. Pacif Div Am Assoc Adv Sci, San Francisco, CA, p 143-174

Ball MD, Arthur JF (1979) Planktonic chlorophyll dynamics in the northern San Francisco Bay and Delta. In: Conomos TJ (ed) San Francisco Bay: the urbanized estuary. Pacif Div Am Assoc Adv Sci, San Francisco, CA, p 265-286

> Beaver JR, Jensen DE, Casamatta DA, Tausz CE and others (2013) Responses of phytoplankton and zooplankton communities in six reservoirs of the middle Missouri River (USA) to drought conditions and a major flood event. Hydrobiologia 705:173-189

Berges JA, Cochlan WP, Harrison PJ (1995) Laboratory and field responses of algal nitrate reductase to diel periodicity in irradiance, nitrate exhaustion, and the presence of ammonium. Mar Ecol Prog Ser 124:259-269

Carlton JT, Thompson JK, Schemel LE, Nichols FH (1990) Remarkable invasion of San Francisco Bay (California, USA), by the Asian clam Potamocorbula amurensis. I. Introduction and dispersal. Mar Ecol Prog Ser 66:81-94

Cloern JE (1999) The relative importance of light and nutrient limitation of phytoplankton growth: a simple index of coastal ecosystem sensitivity to nutrient enrichment. Aquat Ecol 33:3-16

Cloern JE, Jassby AD (2012) Drivers of change in estuarinecoastal ecosystem: discoveries from four decades of study in San Francisco Bay. Rev Geophys 50:RG4001, doi: 10.1029/2012RG000397

Cloern JE, Jassby AD, Carstensen J, Bennett WA and others (2012) Perils of correlating CUSUM-transformed variables to infer ecological relationships (Breton et al. 2006; Glibert 2010). Limnol Oceanogr 57:665-668

> Cole BE, Cloern JE (1984) Significance of biomass and light availability to phytoplankton productivity in San Francisco Bay. Mar Ecol Prog Ser 17:15-24 
Cole BE, Cloern JE (1987) An empirical model for estimating phytoplankton productivity in estuaries. Mar Ecol Prog Ser 36:299-305

Collos Y, Harrison PJ (2014) Acclimation of toxicity of high ammonium concentrations to unicellular algae. Mar Pollut Bull 80:8-23

Collos Y, Vaquer A, Souchu P (2005) Acclimation of nitrate uptake by phytoplankton to high substrate levels. J Phycol 41:466-478

> Cresswell RC, Syrett PJ (1979) Ammonium inhibition of nitrate uptake by the diatom Phaeodactylum tricornutum. Plant Sci Lett 14:321-325

> Dugdale RC, Wilkerson FP, Hogue VE, Marchi A (2007) The role of ammonium and nitrate in spring bloom development in San Francisco Bay. Estuar Coast Shelf Sci 73: $17-29$

Eaton AD, Clesceri LS, Rice EW, Greenberg AE, Franson MAH (eds) (2005) Standard methods for the examination of water and wastewater, 21st edn. American Public Health Association, Washington, DC

Fernandez E, Cardenas J (1989) Genetic and regulatory aspects of nitrate assimilation in algae. In: Wray JL, Kinghorn JR (eds) Molecular and genetic aspects of nitrate assimilation. Oxford University Press, Oxford, p 101-124

- Feyrer F, Herbold B, Matern SA, Moyle PB (2003) Dietary shifts in a stressed fish assemblage: consequences of a bivalve invasion in the San Francisco Estuary. Environ Biol Fishes 67:277-288

Glibert PM (2010) Long-term changes in nutrient loading and stoichiometry and their relationships with changes in the food web and dominant pelagic fish species in the San Francisco Estuary, California. Rev Fish Sci 18: 211-232

Glibert PM, Fullerton D, Burkholder JM, Cornwell JC, Kana TM (2011) Ecological stoichiometry, biogeochemical cycling, invasive species, and aquatic food webs: San Francisco Estuary and comparative systems. Rev Fish Sci 19:358-417

Goodwin P, Denton RA (1991) Seasonal influences on the sediment transport characteristics of the Sacramento River. Proc Inst Civ Eng 91:163-172

Hach Company (2011) Hach water analysis handbook. Hach Company, Loveland, CO, www.hach.com/asset-get. download.jsa?id=7639984158

> He Q, Qiao D, Zhang Q, Li Y and others (2004) Cloning and expression study of a putative high-affinity nitrate transporter gene from Dunaliella salina. J Appl Phycol 16: 395-400

Hildebrand M, Dahlin K (2000) Nitrate transporter genes from the diatom Cylindrotheca fusiformis (Bacillariophyceae): mRNA levels controlled by nitrogen source and during the cell cycle. J Phycol 36:702-713

Hillebrand H, Dürselen CD, Kivschtel D, Pollingsher M, Zohary $\mathrm{T}$ (1999) Biovolume calculation for pelagic and benthic microalgae. J Physiol 35:403-424

> Huppe HC, Farr TJ, Turpin DH (1994) Coordination of chloroplastic metabolism in N-limited Chlamydomonas reinhardtii by redox modulation. Plant Physiol 105: 1043-1048

Jassby AD (2008) Phytoplankton in the upper San Francisco Estuary: recent biomass trends, their causes and their trophic significance. S Francisco Estuar Watershed Sci 6: $1-24$

> Jassby AD, Cloern JE, Cole BE (2002) Annual primary production: patterns and mechanisms of change in a nutri- ent-rich tidal ecosystem. Limnol Oceanogr 47:698-712

Källqvist T, Svenson A (2003) Assessment of ammonia toxicity in tests with the microalga, Nephroselmis pyriformis, Chlorophyta. Water Res 37:477-484

Kimmerer WJ (2002) Effects of freshwater flow on abundance of estuarine organisms: physical effects or trophic linkages. Mar Ecol Prog Ser 243:39-55

Kimmerer WJ, Gartside E, Orsi JJ (1994) Predation by an introduced clam as the likely cause of substantial declines in zooplankton of San Francisco Bay. Mar Ecol Prog Ser 113:81-93

Lehman PW (1996) Changes in chlorophyll a concentration and phytoplankton community composition with wateryear type in the upper San Francisco Bay Estuary. In: Hollibaugh JT (ed) San Francisco Bay: the ecosystem. Pacif Div Am Assoc Adv Sci, San Francisco, CA, p 351-374

Lehman PW (2000) Phytoplankton biomass, cell diameter, and species composition in the low salinity zone of Northern San Francisco Bay Estuary. Estuaries 23:216-230

MacIsaac JJ, Dugdale RC, Huntsman SA, Conway HL (1979) The effect of sewage on uptake of inorganic nitrogen and carbon by natural populations of marine phytoplankton. J Mar Res 37:81-88

Margalef R (1978) Life-forms of phytoplankton as survival alternatives in an unstable environment. Oceanol Acta 1: 493-509

Margalef R, Estrada M, Blasco D (1979) Functional morphology of organisms involved in red tides, as adapted to decaying turbulence. In: Taylor D, Seliger H (eds) Toxic dinoflagellate blooms. Elsevier, New York, NY, p 89-94

McNabb CD (1960) Enumeration of freshwater phytoplankton concentrated on the membrane filter. Limnol Oceanogr 5:57-61

Mitrovic SM, Chessman BC, Davie A, Avery EL, Ryan N (2008) Development of blooms of Cyclotella meneghiniana and Nitzschia spp. (Bacillariophyceae) in a shallow river and estimation of effective suppression flows. Hydrobiologia 596:173-185

Muylaert K, Sabbe K (1996) Cyclotella scaldensis spec. nov. (Bacillariophyceae), a new estuarine diatom. Nova Hedwigia 63:335-345

Nixon SW (1988) Physical energy inputs and the comparative ecology of lake and marine ecosystems. Limnol Oceanogr 33:1005-1025

Nobriga ML, Feyrer F, Baxter RD, Chotkowski M (2005) Fish community ecology in an altered river delta: spatial patterns in species composition, life history strategies and biomass. Estuaries 28:776-785

Pahl SL, Lewis DM, King KD, Chen F (2012) Heterotrophic growth and nutritional aspects of the diatom Cyclotella cryptica (Bacillariophyceae): effect of nitrogen source and concentration. J Appl Phycol 24:301-307

Parker AE, Dugdale RC, Wilkerson FP (2012) Elevated ammonium concentrations from wastewater discharge depress primary productivity in the Sacramento River and the northern San Francisco Estuary. Mar Pollut Bull 64:574-586

Parsons TR, Maita Y, Lalli CM (1984) A manual of chemical and biological methods for seawater analysis. Pergamon Press, Oxford

> Prasad AKSK, Nienow JA, Livingston RJ (1990) The genus Cyclotella (Bacillariophyta) in Choctawatchee Bay, Florida, with special reference to $C$. striata and C. choctawatcheeana sp. nov. Phycologia 29:418-436

Ruhl CA, Schoellhamer DH (2004) Spatial and temporal 
variability of suspended-sediment concentrations in a shallow estuarine environment. $\mathrm{S}$ Francisco Estuar Watershed Sci 2:2-10

Sarthou G, Timmermans KR, Blain S, Treguer P (2005) Growth physiology and fate of diatoms in the ocean: a review. J Sea Res 53:25-42

Schoellhamer DH, Wright SA, Drexler JZ (2012) Conceptual model of sedimentation in the Sacramento-San Joaquin River Delta. S Francisco Estuar Watershed Sci 10:1-25

Smayda TJ (1997) Harmful algal blooms: their ecophysiology and general relevance to phytoplankton blooms in the sea. Limnol Oceanogr 42:1137-1153

Smayda TJ, Reynolds CS (2001) Community assembly in marine phytoplankton: application of recent models to harmful dinoflagellate blooms. J Plankton Res 23: 447-461

Solorzano L (1969) Determination of ammonia in natural waters by the phenohypochlorite method. Limnol Oceanogr 14:799-801

Sommer T, Armor C, Baxter R, Breuer R and others (2007) The collapse of pelagic fishes in the upper San Francisco Estuary. Fisheries 32:270-277

Song B, Ward BB (2007) Molecular cloning and characterization of high-affinity nitrate transporters in marine phytoplankton. J Phycol 43:542-552

Strathmann RR (1967) Estimating the organic carbon content of phytoplankton from cell volume or plasma volume. Limnol Oceanogr 12:411-418

Syrett PJ (1981) Nitrogen metabolism of microalgae. Can Bull Fish Aquat Sci 210:182-210

Editorial responsibility: Max Tilzer, Konstanz, Germany
Syrett PJ (1988) Uptake and utilization of nitrogen compounds. In: Rogers LJ, Gallon JR (eds) Biochemistry of the algae and cyanobacteria. Oxford University Press, Oxford

Thomas WH, Seibert DLR, Dodson AN (1974) Phytoplankton enrichment experiments and bioassays in natural coastal sea water and in sewage outfall receiving water off Southern California. Estuar Coast Mar Sci 2: 191-206

$>$ Thomas WH, Hastings J, Fujita M (1980) Ammonium input to the sea via large sewage outfalls - Part 2: Effects of ammonium on growth and photosynthesis of southern California phytoplankton cultures. Mar Environ Res 3: 291-296

> Thompson JK, Koseff JR, Monismith SG, Lucas LV (2008) Shallow water processes govern system-wide phytoplankton bloom dynamics: a field study. J Mar Syst 74: 153-166

USEPA (1993) Methods for chemical analysis of water and wastewater. Environmental Protection Agency EPA/6QQ/ R-93/100, Cincinnati, OH

> Wehr JD, Descy JP (1998) Use of phytoplankton in large river management. J Phycol 34:741-749

Winder M, Jassby AD (2011) Shifts in zooplankton community structure: implications for food-web processes in the upper San Francisco Estuary. Estuaries Coasts 34: $675-690$

> Yool A, Martin AP, Fernandez C, Clark DR (2007) The significance of nitrification for oceanic new production. Nature 447:999-1002

Submitted: January 29, 2014; Accepted: June 26, 2014

Proofs received from author(s): August 19, 2014 